\title{
Implications of the COVID-19 Pandemic on China's Belt and Road Initiative
}

\section{Frank Mouritz}

George C. Marshall European Center for Security Studies, https://www.marshallcenter.org/en

Universität der Bundeswehr München, https://www.unibw.de/home-en

\begin{abstract}
The article examines the short- and long-term effects of the COVID-19 pandemic on the Belt and Road Initiative (BRI). The temporary shutdown of economies around the world has disrupted global supply chains, which has caused major delays in BRI infrastructure projects and increased the costs. For the time being, China and BRI partner countries will have to divert attention and resources to fighting the spread of the virus and providing relief for their economies. Thus, a serious slowdown for the BRI is inevitable. However, the long-term consequences are still uncertain at this point and will depend, to a large degree, on how long Corona will set back the world economy. China seems determined to carry on with the BRI no matter what, but the question arises if China's economy will recover quickly enough and if Beijing has the financial reserves to keep up the high level of commitment and support for the BRI. If China manages to sustain the BRI throughout the pandemic, Corona can open up opportunities to use "mask diplomacy" and BRI healthcare infrastructure projects to increase Beijing's global standing and the local acceptance for the BRI. Given the changed circumstances, BRI countries are well advised to review their participation in the BRI by giving due consideration to the short-term and possible long-term effects. They should consider if they can still afford these infrastructure projects even if they take longer to finish, are more expensive, and generate a smaller economic impact.
\end{abstract}

Keywords: Silk Road, COVID-19, economic impact, economic recovery, foreign investment 


\section{Introduction}

There is widespread agreement among scientists that one of the most devastating pandemics in human history, the plague or black death, originated in China and spread along the old silk road to Europe. ${ }^{1}$ It demonstrated a pattern that is as old as human history: when people and goods travel, so do bacteria and viruses. Today, there is some speculation about whether COVID-19 circulated along the "new silk road" - China's Belt and Road Initiative (BRI), ${ }^{2}$ and it has even been suggested that the BRI contributed to the spread of the virus. ${ }^{3}$ These kinds of debates are pointless because, even without modern means of transport like planes, cargo ships, and trains, the plague reached the most remote places in the world and killed a large portion of the global population. Interconnectedness might speed up the spread of a pandemic, but being cut off from trade routes and international exchange is no effective protection as the spread of COVID-19 to all parts of the world demonstrates.

However, a real downside of interconnectedness, and its bigger brother globalization, is that a major global disruption, like a pandemic, has ripple effects throughout the world. Inevitably, a global infrastructure development initiative like China's Belt and Road suffers greatly from the interruption of supply chains and restrictions to international travel caused by the Coronavirus. Under the umbrella of the Belt and Road, China is involved in the construction of ports, railways, highways, pipelines, power plants, factories, and many other types of economic infrastructures. The BRI also encompasses other means to increase China's global interconnectivity, such as cooperation on digital technologies, education, and public health (digital, education, and health silk roads), but the infrastructure is at the heart of the initiative. Quick progress on infrastructure development is vital to China's goal to integrate its economy along value chains across Asia, the Middle East, Africa, and Europe. The longer it takes to build the links between China and BRI countries, the longer it will take before China can reap the benefits of its vast investments in the BRI. However, due to the pandemic, BRI infrastructure projects face several serious challenges. Supply lines

1 Giovanna Morelli et al., "Yersinia pestis Genome Sequencing Identifies Patterns of Global Phylogenetic Diversity," Nature Genetics 42, no. 12 (October 2010): 1140-43, https://doi.org/10.1038/ng.705; Stephanie Haensch et al., "Distinct Clones of Yersinia pestis Caused the Black Death," PLoS Pathogens 6, no. 10 (October 2010), https://doi.org/10.1371/journal.ppat.1001134.

2 Salvatore Babones, "The 'Chinese Virus' Spread Along the New Silk Road," Foreign Policy, April 6, 2020 https://foreignpolicy.com/2020/04/06/chinese-coronavirusspread-worldwide-on-new-silk-road; Parag Khanna, "Covid-19 Is Traveling Along the New Silk Road," Wired, February 28, 2020, https://www.wired.com/story/covid-19-istraveling-along-the-new-silk-road.

3 Andreea Brînză, "Some Say China's Belt and Road Helped Create This Pandemic. Can It Prevent the Next One?" The Diplomat, April 2, 2020, https://thediplomat.com/ 2020/04/some-say-chinas-belt-and-road-helped-create-this-pandemic-can-itprevent-the-next-one. 
for raw materials have been interrupted and the production of construction components has been curbed. Some workers have not shown up for work due to lockdown measures or because they are afraid to get infected; anecdotal reports tell of local staff who have refused to work alongside Chinese colleagues. Engineers and construction planners have not been able to travel or are stuck in quarantine. The pandemic also demonstrates a particular vulnerability of BRI projects: dependence on China. Most projects are financed with Chinese money and executed by Chinese construction companies that often employ a large Chinese workforce. Thus, if China's economy struggles, so does the progress of the BRI. A more diversified approach that relies more on local economies would make it easier to substitute raw materials, construction parts and workers. The pandemic would still have negative effects, but it would be easier to adapt to the new situation.

\section{Chinese Promises Are Contradicted by Harsh Realities}

Despite the obvious challenges described above that seriously question the sustainability of the BRI as a whole, a lot of statements of commitment were given by the official Chinese side. China was quick to signal that the BRI would remain a policy priority even amid, and also after, the COVID-19 pandemic. Assurances were given that BRI projects would not be canceled or halted and that there would be no delays. However, given the global ramifications of the pandemic, party officials have had to admit that there would be negative consequences for the BRI. In February 2020, the official account was still that the BRI was "not affected" ${ }^{4}$ by Coronavirus. This position first changed to there being "no serious impact on BRI" ${ }^{5}$ and then, during March, to a "temporary impact on BRI." ${ }^{6}$ In April, after most lockdowns within China had been lifted, the party was quick to announce that Chinese companies were "re-starting most overseas projects." 7 This phrasing is interesting because the word 're-start' indicates that something has been completely stopped and, while there was talk of a "temporary impact," it was never officially acknowledged that work on BRI projects had come to a halt.

The announcement of a BRI restart is clearly contradicted by reports from around the world, which show that a great number of projects are still halted or

4 Zhong Nan, "BRI Projects Not Affected by Coronavirus, Official Says," China Daily, February 21, 2020, https://www.chinadaily.com.cn/a/202002/21/WS5e4f7970a310 12821727952 f.html.

5 Gao Yang, "No Serious Impact of Virus on BRI Projects," China Daily, March 4, 2020, https://www.chinadaily.com.cn/a/202003/04/WS5e5ee134a31012821727c0d3.html.

6 Zhou Jin, "Virus Having Temporary Impact on BRI Construction, Minister Says," China Daily, March 5, 2020, https://www.chinadaily.com.cn/a/202003/05/WS5e60a0d7a31 012821727c9c5.html.

7 Yan Yunming, "Chinese Companies Restarting Most Overseas Projects amid COVID-19 Shows BRI Vitality," Global Times, March 23, 2020, http://www.globaltimes.cn/ content/1186577.shtml. 
can only be continued at a much slower pace. Despite official reassurances that the China-Pakistan Economic Corridor (the BRI's flagship project) will "march forward at full speed," ${ }^{8}$ the Pakistani government eventually had to admit that operations face serious disruptions and delays. ${ }^{9}$ Construction of a high-speed rail financed by China Development Bank (CDB) in Indonesia ${ }^{10}$ and another rail project in Nigeria ${ }^{11}$ has been put on hold. A special economic zone in Cambodia has come to a near standstill ${ }^{12}$ and a power plant that is being built by a Chinese construction company could not start operations in May 2020 as planned. ${ }^{13}$ Delays are also reported for power plants in Myanmar and Bangladesh. ${ }^{14}$ Given the economic uncertainty, some countries have even started to reconsider BRI projects that have already been initialized or are in the planning phase. A large-scale bridge project in Bangladesh is being questioned by local authorities. ${ }^{15}$ The socalled silk-city and five islands project in Kuwait, a megalopolis urban development project, is also under threat ${ }^{16}$ and Thailand has announced that it wants to postpone a high-speed train project with China. ${ }^{17}$ More announcement of delays, halting operations, and renegotiations can be expected as operations are not quickly returned to normal.

8 Wang Bozun, "CPEC to March Forward at Full Speed despite Pandemic: Pakistani FM," Global Times, March 19, 2020, http://www.globaltimes.cn/content/1183171.shtml.

9 Mehtab Haider, "CPEC Projects May Face Delay, Disruption: Report," The News International, April 25, 2020, https://www.thenews.com.pk/print/649536-cpec-projectsmay-face-delay-disruption-report.

10 George Liao, "'One Belt One Road' Begins to Stall in SE Asia as Chinese Economy Reels," Taiwan News, May 6, 2020, https://www.taiwannews.com.tw/en/news/ 3929303.

11 Daniel Russel, Asia Society Policy Institute, "The Coronavirus Will Not Be Fatal for China's Belt and Road Initiative but It Will Strike a Heavy Blow," South China Morning Post, March 19, 2020, https://www.scmp.com/comment/opinion/article/3075624/ coronavirus-will-not-be-fatal-chinas-belt-and-road-initiative-it.

12 Andre Wheeler, "COVID-19: Can China Offset the Long-Term Socio-Economic Impact on China's Belt Road Initiative?" Mizzima, April 15, 2020, http://mizzima.com/article/ covid-19-can-china-offset-long-term-socio-economic-impact-chinas-belt-roadinitiative.

13 Yohei Muramatsu and Shunsuke Tabeta, "Southeast Asia Rail Projects Stall as China Focuses on Recovery," Nikkei Asian Review, May 5, 2020, https://asia.nikkei.com/Spot light/Belt-and-Road/Southeast-Asia-rail-projects-stall-as-China-focuses-on-recovery.

14 Tridivesh Singh Maini, "Coronavirus and It's Impact on the Belt and Road," Modern Diplomacy, March 24, 2020, https://moderndiplomacy.eu/2020/03/24/coronavirusand-its-impact-on-the-belt-and-road.

15 Russel, "The Coronavirus Will Not Be Fatal for China's Belt."

16 Mordechai Chazizza, "The Impact of the Coronavirus Pandemic on China's Belt and Road Initiative in the Middle East," Middle East Institute, April 28, 2020, https://www.mei.edu/publications/impact-coronavirus-pandemic-chinas-belt-androad-initiative-middle-east.

17 "Deferral Sought on Signing Rail Contract," Bangkok Post, April 14, 2020, https://www.bangkokpost.com/business/1899110/deferral-sought-on-signing-railcontract. 
Even when normalization of supply chains and international travel is achieved, it seems unlikely that the BRI can continue as planned. China as well as the countries that signed up to the BRI are faced with serious economic challenges due to the pandemic that could divert attention and resources from the BRI.

\section{The Outlook for China}

For the time being, China is so preoccupied with rescuing its domestic economy that foreign investments may have to take a backseat. According to the National Bureau of Statistics of China, the GDP contracted by $6.8 \%$ in the first quarter of $2020 .{ }^{18}$ Due to the very restrictive lockdown measures across China, most companies have had to shut down and some have never reopened as more than 240,000 bankruptcies were declared in January and February 2020. Probably many more companies went bankrupt during that timeframe but could not declare bankruptcy because most government offices were closed during the first months of the year. The numbers will probably rise even further because $36 \%$ of privately-owned companies reported in February that they did not expect to survive another month of the lockdown, which was only lifted in mid-April. ${ }^{19}$

Few of those companies that survived the pandemic are back to full capacity. Restarting supply chains takes time and requirements for infection control have reduced productivity and increased costs. Export-oriented industry sectors also face the problem of low global demand. Economic output will be significantly lower throughout 2020 and possibly 2021. As a consequence, unemployment is on the rise and will probably hit levels not seen in a long time. Official unemployment numbers increased by 3 million between December 2019 and March 2020 to a record $5.9 \%$. If the 50 million or so migrant workers, many of whom cannot return to their work in the large cities, were to be included in the statistics, the number of people without a job could easily be twice as many. ${ }^{20}$ Many Chinese who have lost their jobs will struggle to repay debts. So, loan default will also be an issue for companies that are already hit hard by the ramifications of the pandemic. China's state-owned banking system can probably absorb large sums of defaulted loans, though nobody actually knows how healthy China's stateowned banks are, but a credit crunch at home will restrict the ability to issue new loans for costly BRI projects. This could cast doubt on projects that are still in the

18 National Bureau of Statistics of China, "Preliminary Accounting Results of GDP for the First Quarter of 2020," April 20, 2020, http://www.stats.gov.cn/english/PressRelease/ 202004/t20200420_1739811.html.

19 Jiayan Feng, "More than 240,000 Chinese Companies Declare Bankruptcy in the First Two Months of 2020," SupChina, April 9, 2020, https://supchina.com/2020/04/09/ more-than-240000-chinese-companies-declare-bankruptcy-in-the-first-two-monthsof-2020.

20 Sun Yu and Christian Shepherd, "China Struggles with Sharp Rise in Unemployment," Financial Times, April 23, 2020, https://www.ft.com/content/5c172455-e967-45a5$84 \mathrm{c} 8-47$ efc3788b08. 
planning phase and will at least result in a cost-benefit review. Chinese investors were, in the past, very quick to grant loans even for economically questionable projects. This will probably change and the riskier investments might be called off. Even well advanced BRI projects might run into problems if the refinancing of older loans becomes more difficult.

Due to the exceptional economic downturn, highlighted by the first contraction of GDP in decades, the communist party leadership is under pressure to refocus attention on domestic investments. Calls for a large stimulus package are growing louder, but the party is still reluctant because it had already introduced several spending programs in the wake of the 2007-2009 global financial crisis. Increased public spending had helped to stabilize the slowing GDP growth in recent years, but returns on investments are shrinking as China becomes more developed. However, there is little alternative to public spending as a means of absorbing the economic shock of the pandemic and, while China has large reserves, they have been dwindling over the last years partly because of BRI financing. This means that China will be forced to spend more carefully and has less financial scope for foreign investments. Already, before the pandemic, posts increased on the Chinese internet calling the BRI a "big spill of money" (in Chinese: da sa bi) which is astonishing as censors try hard to suppress any public criticism of government policies. ${ }^{21}$ The same people are now demanding the prioritization of spending at home and the abandonment of BRI, at least for a while.

\section{The Outlook for BRI Countries}

The situation on the receiving end of the Belt and Road Intiative is similar or even worse. China's partner countries are preoccupied with fighting the pandemic and its economic ramifications. Many countries across Central Asia, the Middle East, and Africa have underfinanced public health systems and are especially vulnerable. For the time being, attention will be devoted to saving lives and stopping the rise of new infections. Countries that are faced with a health emergency are unlikely to have the capacity to push on with their economic development plans.

Unlike China, many BRI countries will not be able to reopen their economies fully for a long time. When they do, economic relief will be required to bolster their economies. Most financial resources will be occupied for that purpose, which limits the funds that can be invested in BRI projects. Many statesmen will come to realize that they cannot afford new highways, railways, pipelines, or ports anymore. Those projects which have already been questioned will become even more under attack from opposition forces and the local public. The ChinaPakistan Economic Corridor has become increasingly unpopular among Pakistanis over time and the government was already struggling to defend the initiative from criticism before the pandemic. Since 2017, five terrorist attacks have

21 "From the Party, with Love: China Releases a Movie Drama Featuring Its Belt-and-Road Project," The Economist, September 5, 2019, https://www.economist.com/china/ 2019/09/05/china-releases-a-movie-drama-featuring-its-belt-and-road-project. 
been directed against the Chinese presence in Pakistan. ${ }^{22}$ Kuwait has also experienced very strong political criticism about the pros and cons of participating in the Belt and Road. ${ }^{23}$ In Central Asia, protests against Chinese economic influence and complaints about their meddling in internal affairs have become more vocal during 2019. ${ }^{24}$ These tendencies will be reinforced if resentment over China as the starting point of the outbreak and its role in spreading the virus outweighs the effects of China's "mask diplomacy," which comprises the provision of medical equipment and advisers to Corona-stricken countries. Countries that feel resentful over China's handling of the outbreak might re-evaluate any closer involvement with China altogether. The pandemic has highlighted the negative consequences of being part of a supply chain that is highly oriented towards China. This could drastically reduce the enthusiasm for being part of the BRI. As can be seen from the above, there are plenty of financial as well as political reasons that may cause countries to postpone, or even cancel, BRI projects.

Even the countries that want to continue with BRI projects as planned might not be able to. As many as $23 \mathrm{BRI}$ countries were already in debt distress before the pandemic ${ }^{25}$ and the cost of fighting the virus and rescuing the economy will further increase the risk of loan defaults. Some of the local contractors that are involved in the construction of BRI projects will go bankrupt during the pandemic, which will cause further logistical problems and delays. The delays due to international supply chain cut-offs and national economic woes will also make BRI projects more expensive. In order to be able to sustain BRI, countries like Cambodia, Kyrgyzstan, Sri Lanka, Pakistan, Djibouti, or Montenegro will need debt relief.

However, it is unlikely that China will write off debts on a large scale. The sums are so high that China cannot afford to waive repayments. According to an analysis by the Kiel Institute for the World Economy, China has lent $50 \%$ more to developing countries than it has officially reported. These "hidden debts" distort the international surveillance of its lending practices. The analysis concludes that the Chinese government and state-owned creditor agencies have granted loans amounting to $\$ 520$ billion to more than 150 countries. Most of these loans were given out in the last years for BRI-related projects. China now accounts for one-

22 Helen Blackwell, "Pakistan Refocuses on Counter-Terrorism to Protect China's Investments," International Institute for Strategic Studies (IISS), September 19, 2019, https://www.iiss.org/blogs/analysis/2019/09/sasia-pakistan-protects-chineseinvestments.

23 Sebastian Castelier, "Can Kuwait's Silk City Project Overcome Islamist Opposition in Parliament?," Al-Monitor, June 5, 2019, https://www.al-monitor.com/pulse/originals/ 2019/06/kuwait-silk-city-bump-unanticipated-obstacles.html.

24 Aruuke Uran Kyzy, "Why Is Anti-Chinese Sentiment on the Rise in Central Asia?," The Diplomat, October 8, 2019, https://thediplomat.com/2019/10/why-is-anti-chinesesentiment-on-the-rise-in-central-asia.

25 John Hurley, Scott Morris, and Gailyn Portelance, "Examining the Debt Implications of the Belt and Road Initiative from a Policy Perspective," Journal of Infrastructure, Policy and Development 3, no. 1 (2019): 139-175, https://doi.org/10.24294/jipd.v3i1.1123. 
quarter of total bank lending to emerging countries and is the largest official creditor, surpassing the World Bank or the IMF. ${ }^{26}$

The China Development Bank and the Export-Import Bank of China (EXIM) have enough resources and the political backing to sustain current lending levels but, due to Corona, an avalanche of demands for loan renegotiations can be expected. China has renegotiated a large amount of BRI related loans-though often, only in exchange for concessions from recipient countries-and it looks like it wants to continue this practice. ${ }^{27}$ In April 2020, the Kyrgyz government announced that it is in active talks with the Chinese government and EXIM bank to reschedule $\$ 1.7$ billion of debts. ${ }^{28}$ However, China might face a domestic backlash over offering better loan terms, especially if their unwillingness to write off loans continues. The most likely scenario is that repayment periods will be prolonged, which will not solve the debt problem but will at least make it possible to continue the expansion of the BRI, for the time being. Whether countries will eventually default on loans depends on the returns that they will get from the completed BRI projects. The record of early BRI projects is mixed, so far, which should not only worry BRI partners but also Beijing. Therefore, the Corona pandemic has become a make-or-break moment for the BRI.

\section{The Way Ahead}

Part of the reason why China initiated the BRI was to maintain high economic growth rates at home by increasing its stake in global value chains and expanding its export markets. Now that Corona has resulted in a drop of GDP (China's economy contracted by 6.8 in the first quarter of 2020), the BRI could become even more important for Beijing's economic strategy to sustain long term growth. The developing world needs foreign investors and loans now more than ever. And, due to Corona, there will be even fewer commercial, as well as public, investors and lenders. China might turn out to be the only country that still has enough reserves to invest in emerging and developing countries. This opens up opportunities to establish new relations with previously skeptical regimes and might force countries to make deals with China simply because there is no alternative at the moment. Corona also offers other opportunities to increase China's standing in the world. Beijing tries very hard to frame itself as a role model for fighting COVID-19 in order to boost its image and deflect from its own failures in the early stage of the outbreak. China was quick to offer medical aid in the form of face

26 Sebastian Horn, Carmen M. Reinhart, and Christoph Trebesch, "China's Overseas Lending," Working Paper 26050 (Cambridge, MA: National Bureau of Economic Research, 2019), https://doi.org/10.3386/w26050.

27 Agatha Kratz, Daniel H. Rosen, and Matthew Mingey, "Booster or Brake? COVID and the Belt and Road Initiative," Rhodium Group, April 15, 2020, https://rhg.com/ research/booster-or-brake-covid-and-the-belt-and-road-initiative.

28 Aida Dzhumashova, "Exim Bank of China to Reschedule Debt of Kyrgyzstan," 24.KG, April 29, 2020, https://24.kg/english/151447_Exim_Bank_of_China_to_reschedule_ debt_of_Kyrgyzstan_. 
masks, respirators, and teams of doctors. This "mask diplomacy" has already produced foreign policy gains. When the EU started to run low on medical protective equipment and stopped exports outside the EU, the EU candidate country Serbia declared that European solidarity was dead and turned to China for help. This incident has the potential to become a turning point for Serbia's international alignment.

The Corona crisis could also provide new impulses to the concept of a "health silk road," which has been mostly overlooked, despite being part of the BRI since 2017. China has a good track record of offering development finance for healthcare infrastructure in Asia and Africa. A stronger focus of the BRI on healthcare could help to increase local acceptance for China's global economic expansion amid growing criticism of its "debt trap diplomacy." The Chinese president Xi Jinping has already started to use the term "health silk road" more often in official conversations. If China turns out to be a major health benefactor during the pandemic, countries that benefit from Chinese aid will have higher trust and be more likely to engage in BRI cooperation. However, it is too early to tell if China can capitalize on the global health crisis. A lot will depend on how good its domestic crisis management is. The faster China's economy recovers, the earlier Beijing can redirect attention and resources to the BRI. The COVID-19 pandemic will, doubtless, be a setback for the BRI, but the next months will decide whether this will be a fatal blow or whether it can evolve into a long-term booster for the BRI along the lines of "what doesn't kill you only makes you stronger."

\section{What Does This Mean for BRI Countries?}

With the future outcome so uncertain, political decision makers in BRI countries are faced with the difficult decision of whether to stick to the BRI and hope for a quick global recovery or to abandon BRI projects in order to minimize losses. The COVID-19 pandemic has deeply altered the cost-benefit calculations of countries participating in the BRI. Projects whose added value was already uncertain before Corona are probably not worth taking further risks anymore. However, some countries are already so heavily invested in the BRI and so deeply indebted to China that they can no longer quit. Other countries might continue to see the $\mathrm{BRI}$ as their only chance for economic development. These countries can only try to mitigate the negative effects of the pandemic as best as possible, which is not an easy thing to do because most disruptions have happened on the Chinese side of the arrangement. Trying to increase resilience by multi-lateralizing BRI projects might be an advisable measure. China has already started to be more open to multi-stakeholder projects as the BRI becomes more and more expensive. Given the backlash created by Corona, chances have increased to convince China to give up part of its control over the BRI. Allowing multilateral institutions and foreign banks to finance BRI projects would not only decrease dependency on China and diversify the risks but also increase transparency and, possibly, even have positive effects on efficiency and sustainability. Renegotiating existing 
loans can give additional breathing room and, while it is unlikely that China will make substantial financial concessions, it offers the opportunity to renegotiate more domestic sourcing and to involve local companies, thus increasing the positive economic footprint in BRI countries. The odds of talking China into more favorable terms of cooperation have never been better because the BRI has become both too important in foreign policy terms and too big in economic terms for it to fail.

\section{Disclaimer}

The views expressed are solely those of the author and do not represent official views of the PfP Consortium of Defense Academies and Security Studies Institutes, participating organizations, or the Consortium's editors.

\section{Acknowledgment}

Connections: The Quarterly Journal, Vol. 19, 2020 is supported by the United States government.

\section{About the Author}

Frank Mouritz is a research associate at the Marshall Center and the Universität der Bundeswehr München. $\mathrm{He}$ is a PhD candidate at the University of Cologne and holds a Master's degree in international politics and East Asia from the University of Warwick, majoring in international political economy of the Asia-Pacific. His research focuses on geoeconomics, international economic interdependencies, and East Asian security. 